\title{
Assessing the value of intangible benefits of property level flood risk adaptation (PLFRA) measures
}

\author{
Rotimi Joseph (Corresponding Author), David Proverbs and Jessica Lamond
}

\begin{abstract}
Studies in the UK and elsewhere have identified that flooding can results in diverse impacts, ranging from significant financial costs (tangible) to social (intangible) impacts on households. At the same time, it is now clear that large scale flood defence schemes are not the panacea to flood risk, and there is an increasing responsibility on property owners to protect their own properties. Hence, there is an emerging expectation for homeowners to take action in the form of investing in property level flood risk adaptation (PLFRA) measures to protect their properties. However, hitherto the level of uptake of such measures remains very low. The tangible financial benefits of investing in PLFRA measures are generally well understood and have been demonstrated to be cost beneficial for many properties at risk from frequent flooding. Importantly, these estimates tend to take little account of the value of the intangible benefits of PLFRA measures and therefore maybe under estimating their full benefits. There remains a need to develop an improved understanding of these intangible benefits and this research sets out to bridge this knowledge gap.
\end{abstract}

Based on a synthesis of the literature, the contingent valuation method (CVM) was selected as a means to value intangible impacts of flooding on households. A questionnaire survey of homeowners affected in the 2007 flooding was employed to elicit Willingness To Pay (WTP) values to avoid the intangible impacts of flooding on their households. The analysis of the questionnaire survey data revealed that the average willingness to pay per household per year to avoid intangible flood impacts was $£ 653$. This therefore represents the value of the intangible benefits of investing in PLFRA measures and is significantly higher than previously estimated. This research builds on previous research in suggesting a higher value to the intangible impacts of flooding on households by assessing wider range of intangible impacts and focussing on more experienced individuals. Furthermore, the research indicates that factors which influence the WTP values were principally stress of flood, worrying about loss of house values, worrying about future flooding, and age of respondents, with income showing a weak correlation. The establishment of a new value for the intangible impacts of flooding on households in the UK is helpful in the domain of flood risk management when evaluating the total benefits (tangible and intangible) of investing in flood protection measures. Thus providing a robust assessment for decision making on flood adaptation measures at an individual property level.

\section{KEYWORDS}

Flood impacts; property level flood risk adaptation measures; willingness to pay; intangible impact; intangible benefits.

Rotimi Joseph, (Corresponding author), PhD researcher, Centre for Floods Communities and Resilience, University of the West of England, Frenchay Campus, Coldharbour Lane, Bristol, BS16 1QY, United Kingdom Rotimi.joseph@uwe.ac.uk. 


\section{Introduction}

Flooding is a global phenomenon which causes widespread devastation, economic damages and loss of human life (Jha, et al., 2012). The dramatic increase in average annual economic and social costs of flood disaster can, to a greater extent, be explained by the effect of climate change, population growth and the increasing urbanisation of societies (Evans et al., 2004; OST 2007). Fay et al (2009) asserted that floods currently account for half of the fatalities across the world arising from natural disasters. In particular, there now appears to be clear evidence that climate change will lead to an increase in the frequency and severity of extreme precipitation and other weather events (IPCC, 2007, IPCC 2012). For the UK this may well result in wetter and stormier winters (UKCIP, 2009). As such, it is predicted that the risk of flooding will at least double by 2080 (Evans et al., 2004) and that annual average damages will rise to some $£ 4$ billion by 2035 (Environment Agency, 2009). It is widely argued that structural flood defences alone are not enough to tackle the level and types of flood risk currently being faced by floodplain residents and that there is a need for a paradigm shift to integrated flood risk management, by balancing structural and non-structural measures (Jha et $a l$,. 2012). Under this paradigm homeowners need to take more responsibility for managing flood risk at an individual property level, if not for the purpose of reducing flood damage on their properties but at least to reduce the intangible impact of their households, by for example, adapting their properties to potential future flood risk (ABI, 2006, Pitt, 2008, Lloyd, 2008, ABI, 2008, Halcrow, 2009, Joseph et al., 2011a).

Flood impacts have long been recognised as complex in nature (Werritty et al., 2007). Whatever the severity of a flood event, the results for the people affected can often be complex and far-reaching. Impacts of flooding on households are both tangible and intangible in nature. Tangible flood impacts are those impacts that are easy to estimate in monetary term, such as the cost of reinstatement or cost of replacing damaged items (Tapsell et al., 2002); whilst the intangible impacts are those that cannot readily be valued but are usually described in qualitative or quantitative terms such as loss of irreplaceable items or items of sentimental value, health impacts and psychological effects of flooding, worrying about the need to be relocated to temporary alternative accommodation (Tapsell et al., 2002; Environment Agency and DEFRA, 2005; Proverbs and Soetanto, 2004 and JBA, 2005). Research has shown that the prospect of a flood event leading to relocating of families to temporary alternative accommodation can adversely affect households more than the physical damage to properties (Environment Agency and DEFRA, 2005 and ABI, 2010).

Thurston et al., (2008) asserted that a key to reducing impacts of flooding on household is the take-up of property level flood risk adaptation measures both in new developments and as part of repair after flood events. Property level flood risk adaptation measures refer to all actions available to homeowners to adapt their properties to flood risk (Joseph et al., 2011b) and involves the process of adjustment of households behaviours to actual or expected flood risk in order to reduce its impacts on households (IPCC, 2012). These include collective process of either keeping water out - resistance measures or allowing the water into the property but reducing the damage caused to the fabric of the property - resilience measures (ABI, 2003, Thurston et al., 2008, Beddoes and Booth, 2011, Wassell et al., 2009, Joseph et 
al., 2011b, Warren et al., 2011, JBA, 2012, Royal Haskoning, 2012), thereby allowing quick reinstatement of the property after flood water has receded. In addition, property can be adapted to flood risk by relocating expensive items from ground floor to upper floor or by registering for flood alert warning (Walker et al., 2008, Priest et al., 2008). Mark (2008) argues that measures that minimize population displacement and favour an early return of victims to routine activities of daily living are known to lessen the adverse impact of flooding. However, due to the inherent difficulty in the assessment of the intangible impact of flooding, cost benefit assessment of the PLFRA measures are often carried out without including the value of intangible benefits in the assessment, thereby providing incomplete information (Joseph et al., 2011a).

Research has shown that floodplain residents are reluctant to adopt resistance and resilience measures in the aftermath of a flood event (Harries 2007, ABI 2010) and this may be attributed to reasons such as informational barriers, emotional constraints, aesthetic considerations, timing issues (Proverbs and Lamond 2008). Further, research by different stakeholders: practitioners (Flood Repair Forum, 2006) academics (Soetanto et al., 2008, Joseph et al., 2011b), Government, (Office of the Deputy Prime Minister, 2003, Bowker et al., 2007, Thurston et al., 2008) and the insurance industry (ABI, 2003, ABI, 2006, Wassell et al., 2009) has examined the costs and effectiveness of installing property level resistance and resilience measures. To some extent, much of the previous research was not directed at helping individual homeowners' decision making and so not appropriate for that purpose. In particular, intangibles are far more important for homeowners to consider because they are the ones that suffer in the aftermath of flood event. In the light of this and with the wider acceptance by different authors that the intangible impacts are large and important (Green and Penning-Rowsell, 1989, Lekuthai and Vongvisessomjai, 2001, Werritty et al., 2007, Environment Agency, 2010), there is therefore a need to carry out a comprehensive assessment of the value of intangible benefits of property level flood risk adaptation (PLFRA) measures to be used in the domain of flood risk management research, most especially when assessing the financial cost benefit of investing in PLFRA measures. The purpose of this research was to address this gap in the understanding of PLFRA measures.

In order to addressing the gap identified, the locations, which experienced flood event in the summer 2007 flood event were used, the 2007 flood event was reported to be widespread and catastrophic in nature (Chatterton et al., 2010). The major advantages of choosing this large scale national flood event as the basis for the empirical study was that the number of properties affected was large in UK terms, therefore, if well dispersed, would provide maximum data for the research. For instance, the estimated insured losses were the largest flood losses in insurance history for the UK (Stuart-Menteth, 2007). The 2007 summer was the wettest summer since records began in over 250 years (EA, 2007), with extreme levels of rainfall compressed in relatively short periods of time. The flood events were linked to a pattern of very wet and unstable weather across the UK over the course of several months. The unseasonably wet weather began in May and continued throughout the summer, with record-breaking rainfall totals in June and July (Stuart-Menteth, 2007; EA, 2007; Pitt, 2008). 
While the research focus was on the summer 2007 flood event, which was reported to be widespread, it was considered necessary to select sites for the analysis, because it is impractical to include all the flooded locations in the sample size due to time constraints. However, the selected sites can be said to be representative of flooded regions during the summer 2007 flood event. Selection of the analysis sites from the locations flooded during the 2007 event was based on the need to represent the widest possible variation both geographical and flood typology while retaining minimum numbers of properties within each selected site. To that end only sites with greater than 50 affected properties were considered.

\section{Methodology}

The conventional approach to flood damage mitigation measures at household levels takes into consideration only the tangible impacts of flooding; this is a determination that is considered to be insufficient for any sound decision-making by homeowners when considering investing in PLFRA measures. There are economic valuation methods which are recognised as suitable to arrive at monetary estimates of non-monetary goods and therefore can be used to estimate the intangible impact of flooding on households. The most commonly used economic valuation methods are the revealed preference method (RPM) and the stated preference methods (SPM).

\subsection{Choice of method for quantification of intangible impacts of flooding on households}

The revealed preference methods (RPM) are also known as indirect valuation methods, the RPMs look for related or substitute markets in which the environmental good is implicitly traded, the information derived from observed behaviour in the substitute markets is used to estimate willingness to pay (WTP), which represents individual's valuation of, or the benefits derived from, the investment in flood protection measures. The main weakness of this potential method in the context of this study is the inability of RPM methods to distinguish between behaviour driven by tangible and intangible impacts. Whilst, the stated preference methods (SPM), are called direct valuation methods or inferential methods (Penning-Rowsell et al., 2005), they have been developed to solve the problem of valuing intangible impacts/losses that have no obvious market value (Birol et al., 2006). The SPMs use survey techniques to infer the value of something that does not have an observable price (PenningRowsell et al., 2005). They are survey or experiment-based approaches that elicit people's preference directly and can be designed to distinguish WTP for specific impacts.

Two main methods of SPM are contingent valuation method (CVM) and choice modelling method (CMM). Both methods use similarly structured questionnaires but differ in the way they define the non-market effect of concern. In addition to their ability to estimate user costs / values of any environmental impact on people, the most important feature of these surveybased methods is that they can be used to elicit the value of intangible impacts on households. In this research CVM was used to elicit specific information from homeowners with regard WTP to avoid intangible impacts. 
The CVM approach asks people to directly report their willingness to pay (WTP) to obtain a specified good or service, or willingness to accept payment (WTA) to give up a good or service. In the context of flooding; CVM depends upon a hypothetical situation or scenario whereby samples of floodplain residents are asked to state their maximum WTP in order to avoid or reduce the identified intangible impacts of flooding on their households. Mitchel and Carson (1989) advised that because CVM is a social survey approach it is very important to pay special attention to the design and implementation of the survey questions and sample design.

One of the main strengths of the CVM is that respondents are given the opportunity to state what they are willing to pay or what compensation they are willing to accept in order to reduce or eliminate the intangible impacts of flooding. However, one of the challenges of using the CVM in the domain of flood risk management research is the need to consider the ethical issues in the design of questions, so as to protect the interests of research participants. However a well designed questionnaire should be able to address this concern. It is recognised that the WTP stated by individual may be subject to their disposable income as there are income differentials among the floodplain residents; this could cause inherent bias towards the preferences of the better off. In order to address these drawbacks, analysis of the factors which influence respondents WTP needs to examine the relationship between income and stated WTP values.

One of the problems associated with the use of CVM in eliciting the value of willingness to pay is the possibility of hypothetical bias. Mitchell and Carson (1989) and Whittington et al. (1991) argued that the more a respondent is familiar with the good, the less will be the level of hypothetical bias in a CVM. This implies that the WTP values elicited for those public goods, which are traded in the markets or which the individuals are familiar with, would be free from hypothetical bias, thus, by targeting respondents who have been flooded before and are familiar with the intangible impacts of flooding, the problem of hypothetical bias is reduced.

\subsection{Survey Instrument}

An extensive floodplain resident consultation was undertaken to gain a better understanding of the perception of flood experience by floodplain residents; the benefits of investing in PLFRA measures and their willingness to pay to reduce the impact of flooding on their households. This contributed to the evidence base needed to inform the effective promotion of PLFRA measures. The consultation took the form of postal questionnaire surveys. For similar studies where questionnaire surveys have been used successfully see Markandya, 1997; Hashimoto, et.al (2006) and Gee and Burkhard (2010). Online survey distribution system was considered at the outset of the research. This was dismissed because the mix of the targeted population, which comprises of all adult of age groups and diverse socioeconomic profiles. It was anticipated that not all of them would have easy access to the internet in order to be able to complete the questionnaire. Further the email addresses to be used for this method of distribution were not readily available. The survey questionnaire was designed to gather information in three key areas: 
1. socio economic demographics

2. Flood experience (previous and subsequent flood experiences)

3. Severity of the impact of flooding on households and the maximum amount they are willing to pay to reduce the impacts

Prior to distributing the questionnaire to the main respondents, it was subjected to the scrutiny of the University ethics committee owing to the sensitive nature of some of the questions. A pilot survey was conducted among homeowners who were not part of the main survey to determine the suitability of the questionnaire format and the contents, before being distributed by postal method to the areas affected by the summer 2007 flood event (see Figure 1). The feedback received from the pilot survey showed that the questions were easy to understand, although some respondents were unable to provide the amount they were willing to pay to reduce intangible impact of flooding on their households. The reason provided was that it was not possible to place a value on intangible impact such as 'stress, worry'. Drawing from previous studies (Environment Agency and DEFRA, 2005) comments such as this were not unexpected, therefore, it was decided that the main questionnaire survey could proceed.

\subsection{Implementation of CVM survey}

In total, 2309 questionnaires were distributed via post to homeowners. The survey yielded 280 responses, representing a response rate of $12.1 \%$, which is considered a reasonable return for an unsolicited postal survey. The low response rate can be attributed to the nature of the information required to be provided by the survey participant. In any good research ethical considerations are of paramount importance. Respondents were provided with a separate letter advising them not to open the questionnaire if they thought that by remembering the flood event of 2007, it would cause them any distress as some of the questions may bring back the memory of the event. Further, some of the residents moved out of the areas after the flood event. Thus, owing to the sensitive nature of the research, a response rate of $12.1 \%$ can be considered adequate and valid for the purposes of analysis. The analyses of the survey data are presented in the next section. 


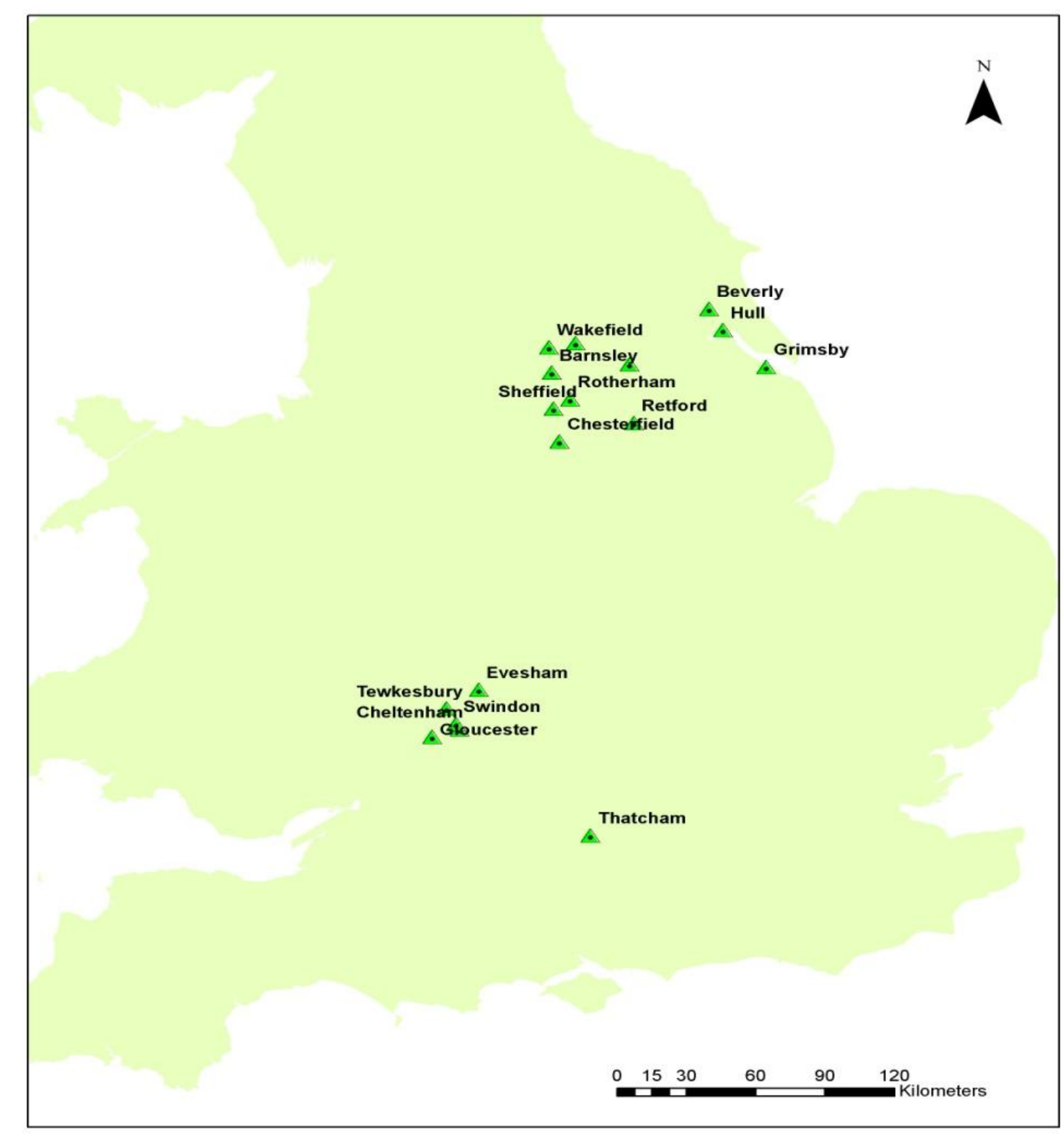

Figure 1. Survey Site Locations

\section{Findings and discussion}

Detailed analysis of the dataset is carried out and presented in this section. By employing appropriate statistical techniques such as descriptive statistic analysis on the participants flood experience; relative importance index (RII) test to rank the severity of flood impact on participants' households; and correlation analysis to determine the relationship between value of WTP and the intangible flood impacts. Further, detailed analysis of the factors which influence the stated WTP values is presented. This section is completed by presenting the value of WTP which represents the intangible benefits of investing in PLFRA measures. 


\subsection{Previous and subsequent flood experience}

Respondents were asked if they had experienced flood damage to their properties before 2007. Most respondents (77.9\%) had no previous flood experience prior to the 2007 flood event; $16 \%$ reported that they had experienced one previous flood to their properties prior to the 2007 event; and approximately $4 \%$ had been flooded twice and $3 \%$ had been flooded more than twice. This information is important because it is anticipated that the value of WTP stated by respondents would relate to their individual flood experiences. Further, it has been shown that experience of flooding can be a source of motivation to individuals to undertake precautionary measures against flooding (Kreibich et al., 2011; Koerth et al., 2013).

Further, respondents were asked if they had experienced a flood event following the 2007 flood event. Some $91 \%$ of respondents did not experience a flood event after the 2007 summer flood event. This means that only $9 \%$ of respondents had experienced further flooding after 2007. It is anticipated that this finding would not have significant impact on the value of WTP derived from this research because most of the respondents have been flooded at least once, therefore they are in a best position to make judgement on WTP to avoid similar flood impacts to those experienced when they were flooded in 2007.

\subsection{Impact of flooding on households and willingness to pay to reduce the impacts}

Information on the severity of the intangible impact of flooding on households and the extent of this was gathered using a five-point Likert scale ranging from 'extreme impact' to 'no impact'. A weighting was allocated to each extent; where '"extreme impact' = 5, 'high impact' $=4$, 'moderate impact' $=3$, 'marginal impact' $=2$, 'no impact' $=1$ '. The relative importance index (RII) method was used to rank the responses obtained from the Likert scale questions. RII is a method used to evaluate the comparative importance of a single item to others (Yang and Wei, 2010) and has been used successfully to rank factors according to their relative importance in construction research (Ramanathan et al., 2012) and flood related research (Wedawatta et al., 2013).

Table 1 presents the RII values for effects and the consequent ranking of factors. Accordingly, 'stress of flood event' ( 0.80$)$ was the top-ranked impact, closely followed by 'worrying about loss of house value' (0.77). Low ranked impact was 'deterioration of physical health' (0.44). The result concurred with other related studies such as Environment Agency and DEFRA, (2005) and Bichard and Kazmierczak, (2009) which found that stress of flood event is the considered by respondents as the intangible impact of flooding which affects their households the most. 
Table 1 Ranking of severity of intangible flood impacts according to relative importance index (RII) values

\begin{tabular}{|c|c|c|c|c|c|}
\hline Flood Impacts & $\begin{array}{c}\text { No of Responses } \\
\text { with the highest } \\
\text { weight }\end{array}$ & $\begin{array}{l}\text { No of } \\
\text { responses } \\
\text { with no } \\
\text { impact }\end{array}$ & $\begin{array}{l}\text { Mean Impact } \\
\text { weight }\end{array}$ & $\begin{array}{c}\text { Relative } \\
\text { Importance } \\
\text { Index (RII) }\end{array}$ & $\begin{array}{l}\text { Ranks* } \mathbf{R} \\
\text { (Based on } \\
\text { RII value) }\end{array}$ \\
\hline Stress of flood & 206 & 2 & 4.01 & 0.80 & 1 \\
\hline $\begin{array}{l}\text { Worry about loss of house } \\
\text { value }\end{array}$ & 192 & 14 & 3.83 & 0.77 & 2 \\
\hline Worry about future flooding & 183 & 16 & 3.79 & 0.76 & 3 \\
\hline Destruction of property & 171 & 16 & 3.71 & 0.74 & 4 \\
\hline $\begin{array}{l}\text { Increase in insurance } \\
\text { premium }\end{array}$ & 167 & 25 & 3.64 & 0.73 & 5 \\
\hline $\begin{array}{l}\text { Time to return to normal } \\
\text { household activity }\end{array}$ & 160 & 17 & 3.63 & 0.73 & 6 \\
\hline Dealing with insurers & 154 & 9 & 3.56 & 0.71 & 7 \\
\hline Dealing with builders & 142 & 21 & 3.48 & 0.69 & 8 \\
\hline $\begin{array}{l}\text { Having to leave home for } \\
\text { longer period }\end{array}$ & 151 & 70 & 3.22 & 0.64 & 9 \\
\hline $\begin{array}{l}\text { Loss of } \\
\text { irreplaceable/sentimental } \\
\text { items }\end{array}$ & 130 & 55 & 3.16 & 0.63 & 10 \\
\hline $\begin{array}{l}\text { Inability to obtain insurance } \\
\text { cover }\end{array}$ & 100 & 99 & 2.72 & 0.54 & 11 \\
\hline $\begin{array}{l}\text { Disruption of livelihood and } \\
\text { income }\end{array}$ & 73 & 113 & 2.38 & 0.48 & 12 \\
\hline Strains between family & 57 & 100 & 2.33 & 0.47 & 13 \\
\hline $\begin{array}{l}\text { Deterioration to mental } \\
\text { health }\end{array}$ & 63 & 122 & 2.26 & 0.45 & 14 \\
\hline $\begin{array}{l}\text { Deterioration to physical } \\
\text { health }\end{array}$ & 53 & 115 & 2.18 & 0.44 & 15 \\
\hline
\end{tabular}

*Equal RII values ranked according to the number of responses with the highest weight

\subsection{Review of Willingness to Pay (WTP) data}

Survey participants were asked to state the maximum amount they were willing and able to pay to avoid or reduce the identified intangible impact of flooding. In total, out of the 280 responses, $251(89.6 \%)$ provided WTP values which ranged from $£ 0$ to $£ 5000$ to avoid impact of flooding on households and $£ 0$ to $£ 10,000$ to avoid psychological effect of flooding on households. As in other contingent valuation method studies such as Özbafli (2011), there is always a potential for "protest" WTP values stated by respondents, therefore, it was considered necessary to carry out a proper screening of the WTP values for protest bids.

The results of the review suggested that there were two potentially invalid WTP responses on the basis that the WTP values represented $11 \%$ and $29 \%$ of their household incomes for the two respondents. Detailed examination of the respondents' responses indicated that both respondents had significantly bad experience during the 2007 flood event as detailed in the comment box within the questionnaire. Based on this, it was obvious that they were negatively affected by the flood event, therefore their stated WTP values may have been emotionally influenced by their experience; on this basis the WTP values were deemed to be invalid and were not included in the analysis.

Detailed review of zero (0) WTP value revealed that there were six respondents who stated zero WTP as a protest bid. Based on this and in order to avoid introducing a bias in the WTP 
analysis by including invalid zero value in both sets of WTP (i.e. on impacts and psychological effects), the usual practice was followed by removing the six protest responses from the WTP analysis (see O'Garra et al., 2007, Birol et al., 2008 and Özbafli, 2011 for a similar treatment of protest responses). Within the remaining 243 responses on WTP to reduce flood impact on households, 7 (3\%) were true zero WTP value, whilst on WTP to reduce psychological effect of flooding on households, $27(11.1 \%)$ were true zero WTP value. Therefore the analysis that follows was based on 243 responses for avoiding impact and psychological effect of flooding on households.

As shown in Figure 2, the total amount homeowners were willing to pay to avoid impact and psychological effects of flooding on their households ranged from $£ 0$ to over $£ 1,200$, with $45 \%$ and $65 \%$ of respondents willing to pay between $£ 0$ to $£ 299$ to avoid the intangible impacts and psychological effects of flooding on their households respectively; in additional to this, some $17 \%$ and $10 \%$ of the respondents stated that they are willing to pay between $£ 500$ to $£ 599$ to avoid the impact and psychological effect of flooding on their households respectively. Prior to determining the actual WTP values, detailed analyses of the factors which influence respondents' stated WTP values were carried out. These are discussed in the following sections.

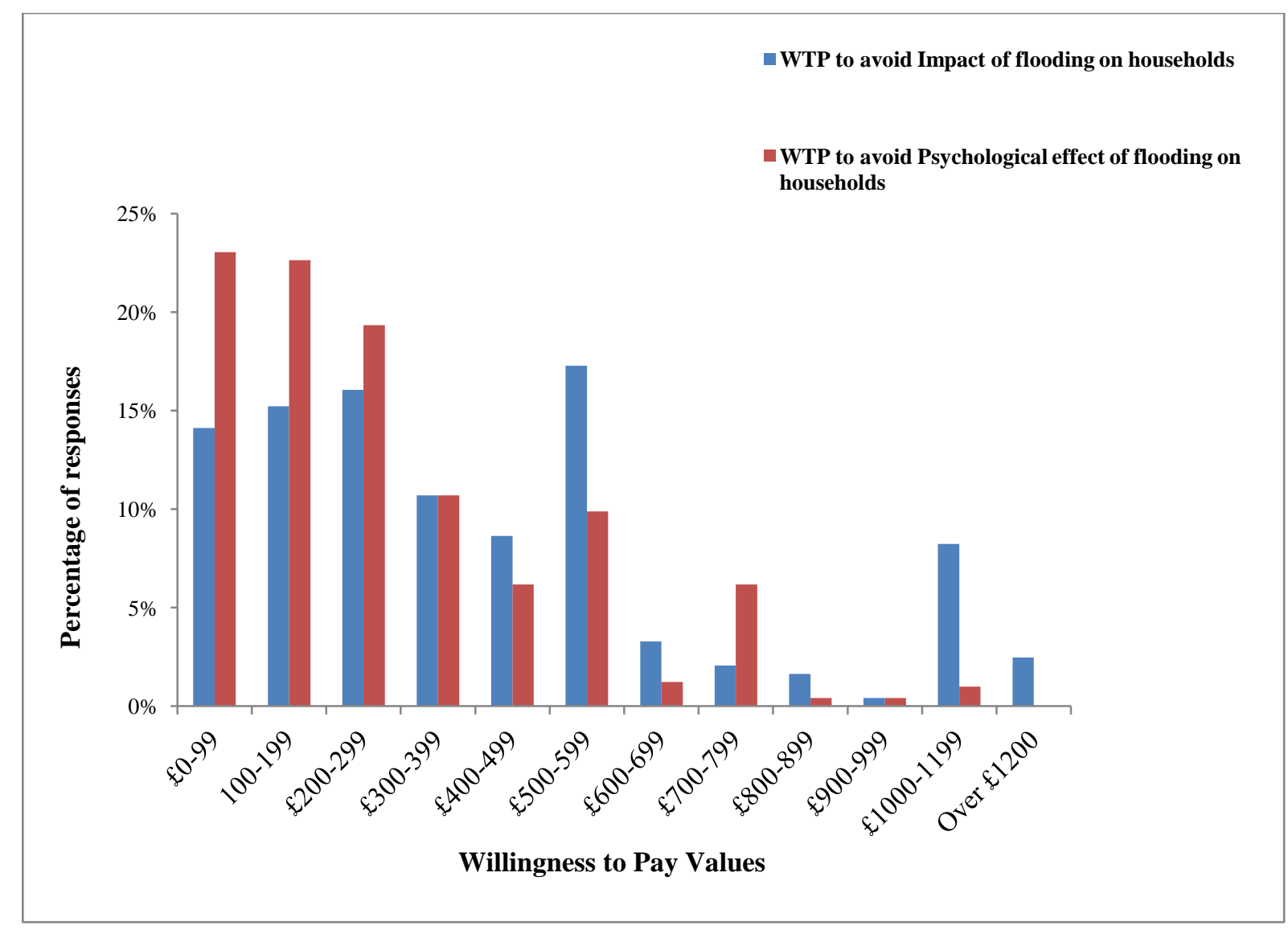

Figure 2. Willingness to pay to reduce impact and psychological effect of flooding on households 


\subsection{Review of factors influencing Willingness to Pay (WTP) values}

Previous studies in the area of estimating value of intangible impact of flooding have suggested that factors such as household income levels, age of respondents, stress of flooding and perhaps number of people in the household, to some extent affect individual WTP values (Environment Agency and DEFRA, 2005). Therefore, further analyses of the survey data was carried out to explore the factors which influence the respondents' stated WTP values.

Likert scale responses for the impact of flooding and responses received on WTP were thus subjected to correlation analysis, with the intention of developing a correlation matrix identifying possible relationships and WTP driving factors that may exist between them. Soetanto and Proverbs (2004) used a correlation matrix to investigate the relationships between building surveyors' levels of experience and their perceived levels of importance towards flood characteristics. In this research, Spearman's rank order correlation was used to arrive at the correlation matrix, as the data used were ordinal and there is presence of outliers in the WTP values. According to Field (2009) and Blaikie (2010), Pearson's Correlation Coefficient is sensitive to skewed distribution and outliers. Similarly, Grothmann and Reusswig (2006) have used Spearman's correlation to construct a correlation matrix for the factors affecting flood protective responses of residents at risk of flooding.

Table 2 shows the Spearman's rank correlation values for the flood impacts experienced by the households and the value of WTP. The results show that there is a strong correlation between the respondents WTP values and the stress of flood $\left(r_{s}=0.46, \mathrm{r}=0.00\right)$. This is further confirmed by the fact that stress of flood impact was ranked as the highest severity impact of the flood event on their households (see Table 1). Strong positive correlation is observed between worrying about future flooding and WTP values $\left(r_{s}=0.42, \mathrm{r}=0.00\right)$. Moderate correlations are recorded between the following flood impacts and WTP values; worrying about loss of house value $\left(r_{s}=0.39, \mathrm{r}=0.00\right)$; worrying about increase in insurance premium $\left(r_{s}=0.25, \mathrm{r}=0.00\right)$ and worrying about having to leave home $\left(r_{s}=0.23, \mathrm{r}=0.00\right)$. The results concur with the results of the ranking of the severity of flood impacts presented in Table 1. Although, the impact of having to leave home was ranked $9^{\text {th }}$ on the RII table, but when compared to other impacts, it shows a moderate correlation, which means that it is one factor which influences respondents WTP values. Other variables such as income; age of respondents; number of people in households and occupation of respondents demonstrate weak correlations with the WTP values. Further analysis was carried out on these four factors to ascertain if they actually influence respondents' WTP values.

\section{Willingness to pay (WTP) by household income levels}

Many contingent valuation method (CVM) studies found weak income effects due to the difficulties in measuring households income for instance, high non-response rate, intentional misrepresentation of respondent's income, failing to include income from all sources (Alberini, 2004). In addition to this, the likelihood of having a significant income effect has been related to the sample size and the design choices made in the study (Broberg, 2010). Mean WTP values based on income levels of each of the respondents was analysed. Figure 3 
shows the result of this analysis. This result confirmed that higher income does not necessarily means higher WTP values. Meaning that the WTP values stated by respondents appear not to have significant relationship with households' income which explains the weak correlation coefficient recorded $\left(r_{s}=0.032\right)$. When compared, the WTP to reduce impact and psychological effect of flooding for respondents that earn less than $£ 5,000$ with those that earn over $£ 55,000$, there were $15.7 \%$ and $20.4 \%$ difference in the mean WTP values for both income levels. Based on these findings, it can be inferred that the stated WTP values by flooded respondents are not influenced by the household income level. This can be linked to the fact that higher income earners may have better insurance cover than low income earners, by having additions to their normal domestic insurance policy in which case the premium they pay will reflect this. Based on this, they may have less stressful dealings with insurers and builders as a result and be of the opinion that they are fully covered, and this can have significant influence on their stated WTP values. Equally high income earners may be more likely to consider themselves 'self insured' because they could afford to replace things straight away, pay extra phone bills and have more choice about their alternative accommodation. This assumption and feeling of greater control over events can influence the stated WTP by high income earners.

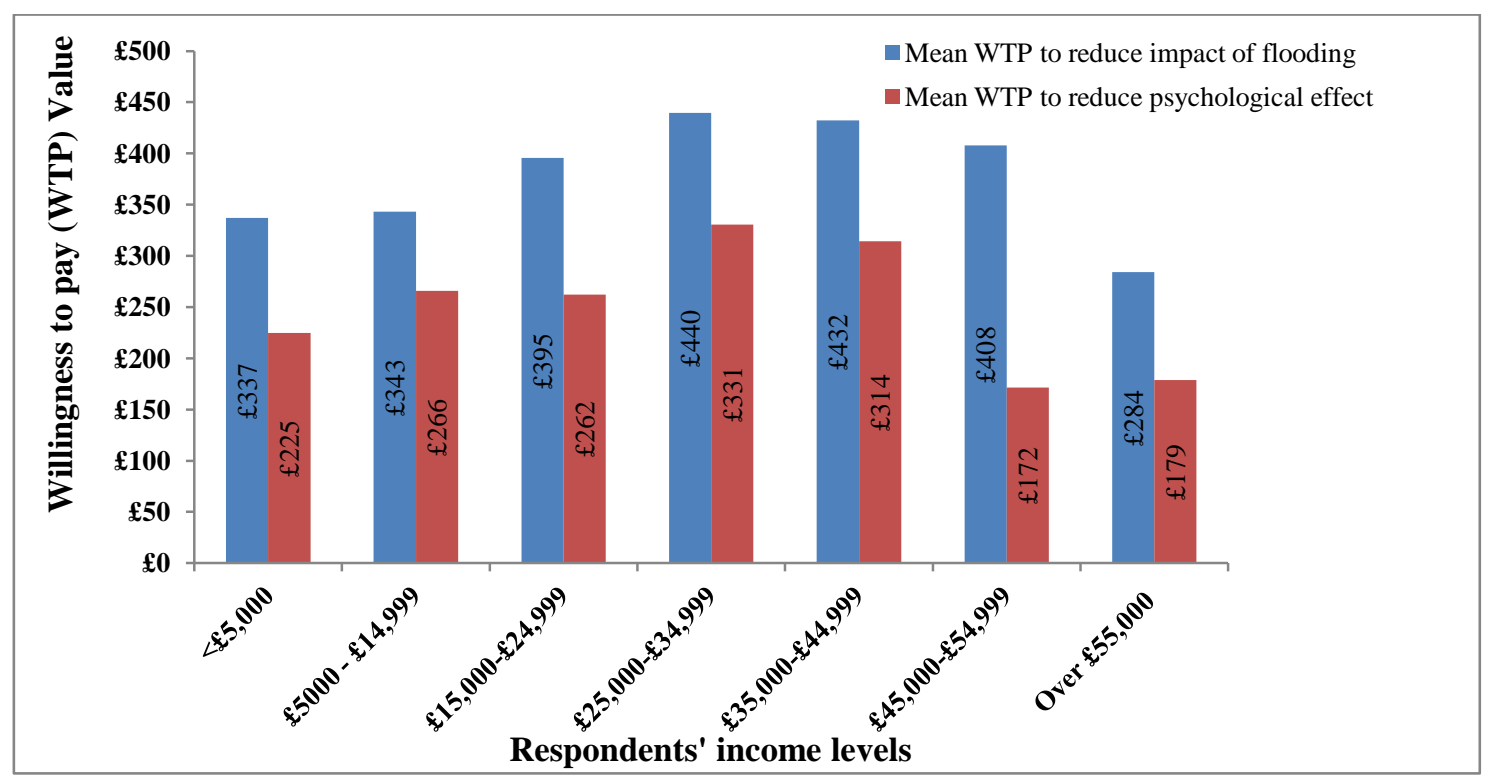

Figure 3 Mean WTP values based income level of household income earner 
Table 2 correlation between flood impacts, willingness to pay and socio economic status

\begin{tabular}{|c|c|c|c|c|c|c|c|c|c|c|c|c|c|c|c|c|c|c|c|c|c|c|}
\hline & Factors & & 1 & 2 & 3 & 4 & 5 & 6 & 7 & 8 & 9 & 10 & 11 & 12 & 13 & 14 & 15 & 16 & 17 & 18 & 19 & 20 \\
\hline 1 & Willingness to Pay & $\begin{array}{l}\text { Correlation Coefficient } \\
\text { Sig. (2-tailed) }\end{array}$ & 1.000 & & & & & & & & & & & & & & & & & & & \\
\hline \multirow[t]{2}{*}{2} & $\begin{array}{l}\text { Number of people living in } \\
\text { household }\end{array}$ & Correlation Coefficient & .052 & 1.000 & & & & & & & & & & & & & & & & & & \\
\hline & Household income level & $\begin{array}{l}\text { Sig. (2-tailed) } \\
\text { Correlation Coefficient }\end{array}$ & $\begin{array}{l}.422 \\
.032\end{array}$ & $.218^{* *}$ & 1.000 & & & & & & & & & & & & & & & & & \\
\hline \multirow{2}{*}{4} & Age of respondents & $\begin{array}{l}\text { Sig. (2-tailed) } \\
\text { Correlation Coefficient }\end{array}$ & .624 & .001 & $360^{* \prime}$ & 1.000 & & & & & & & & & & & & & & & & \\
\hline & 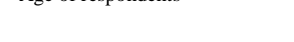 & Sig. (2-tailed) & .226 & .000 & .000 & & & & & & & & & & & & & & & & & \\
\hline \multirow[t]{2}{*}{5} & $\begin{array}{l}\text { Occupation of the main income } \\
\text { earner }\end{array}$ & Sig. (2-tailed) & .012 & $-.174^{* * *}$ & $-.611^{* *}$ & $.652^{* *}$ & 1.000 & & & & & & & & & & & & & & & \\
\hline & & Sig. (2-tailed) & .852 & .006 & .000 & .000 & & & & & & & & & & & & & & & & \\
\hline \multirow[t]{2}{*}{6} & Stress of flood impact & Correlation Coefficient & $.458^{* *}$ & -.065 & $-.168^{* *}$ & -.019 & .117 & 1.000 & & & & & & & & & & & & & & \\
\hline & & Sig. (2-tailed) & .000 & .310 & . 008 & .770 & .069 & & & & & & & & & & & & & & & \\
\hline \multirow[t]{2}{*}{7} & Having to leave home & Correlation Coefficient & $.231^{* *}$ & -.059 & $-.207^{7^{*}}$ & . 049 & .104 & $.528^{* *}$ & 1.000 & & & & & & & & & & & & & \\
\hline & & Sig. (2-tailed) & .000 & .359 & .001 & . 449 & .106 & .000 & & & & & & & & & & & & & & \\
\hline \multirow[t]{2}{*}{8} & Dealing with insurer & Correlation Coefficient & .124 & -.083 & -.032 & -.111 & -.054 & $.412^{* *}$ & $.476^{* *}$ & 1.000 & & & & & & & & & & & & \\
\hline & & Sig. (2-tailed) & .054 & .197 & .619 & . 084 & .402 & .000 & .000 & & & & & & & & & & & & & \\
\hline \multirow[t]{2}{*}{9} & Dealing with builders & Correlation Coefficient & $.173^{* *}$ & -.053 & -.017 & -.113 & -.058 & $.350^{* *}$ & $.443^{* *}$ & .613"* & 1.000 & & & & & & & & & & & \\
\hline & & Sig. (2-tailed) & .007 & .409 & .794 & .078 & .367 & .000 & .000 & .000 & & & & & & & & & & & & \\
\hline \multirow[t]{2}{*}{10} & $\begin{array}{l}\text { Time and effort to return to } \\
\text { normal }\end{array}$ & Correlation Coefficient & $.195^{* *}$ & .036 & $-.150^{*}$ & .042 & $.132^{*}$ & $.517^{* *}$ & $.476^{* *}$ & $.451^{* *}$ & $.407^{* *}$ & 1.000 & & & & & & & & & & \\
\hline & & Sig. (2-tailed) & .002 & .573 & .020 & .515 & .039 & .000 & .000 & .000 & .000 & & & & & & & & & & & \\
\hline \multirow[t]{2}{*}{11} & Worrying about future flooding & Correlation Coefficient & .421"* & -.027 & $-.132^{*}$ & -.006 & . 072 & $.452^{* *}$ & $.286^{* \prime \prime}$ & $.273^{* *}$ & . 097 & $.486^{* *}$ & 1.000 & & & & & & & & & \\
\hline & & Sig. (2-tailed) & .000 & .678 & .040 & .923 & .262 & .000 & .000 & .000 & .130 & .000 & & & & & & & & & & \\
\hline \multirow[t]{2}{*}{12} & Strains between family & Correlation Coefficient & .118 & . $180^{* *}$ & -.070 & -.122 & -.019 & $.402^{* *}$ & $.378^{* *}$ & $.310^{* *+}$ & $.315^{* *}$ & $.478^{* *}$ & $.325^{* *}$ & 1.000 & & & & & & & & \\
\hline & & Sig. (2-tailed) & .066 & .005 & .276 & .058 & .770 & .000 & .000 & .000 & .000 & .000 & .000 & & & & & & & & & \\
\hline \multirow[t]{2}{*}{13} & Deterioration of physical health & Correlation Coefficient & $.127^{*}$ & -.039 & $-.204^{* *}$ & .072 & $.153^{*}$ & $.531^{* *}$ & $.418^{* *}$ & $.322^{* * *}$ & $.232^{* *}$ & $.488^{* *}$ & $.385^{* *}$ & $.534^{* *}$ & 1.000 & & & & & & & \\
\hline & & Sig. (2-tailed) & .049 & .543 & .001 & .263 & .017 & .000 & .000 & .000 & .000 & .000 & .000 & .000 & & & & & & & & \\
\hline \multirow[t]{2}{*}{14} & Deterioration of mental health & Correlation Coefficient & $.159^{*}$ & .102 & $-.178^{* *}$ & -.048 & .095 & $.452^{* *}$ & $.421^{* *}$ & .409" & $.309^{* *}$ & $.460^{* *}$ & $.266^{* *}$ & $.536^{* *}$ & $.652^{* *}$ & 1.000 & & & & & & \\
\hline & & Sig. (2-tailed) & .013 & .114 & .006 & .454 & .141 & .000 & .000 & .000 & .000 & .000 & .000 & .000 & .000 & & & & & & & \\
\hline \multirow[t]{2}{*}{15} & Loss of irreplaceable item & Correlation Coefficient & .092 & -.072 & $-.180^{* *}$ & .030 & .062 & $.343^{* *}$ & $.408^{* *}$ & $.208^{* *}$ & $.153^{*}$ & $.275^{* *}$ & $.181^{* *}$ & $.216^{* *}$ & $.309^{* *}$ & $249^{* *}$ & 1.000 & & & & & \\
\hline & & Sig. (2-tailed) & .151 & .261 & .005 & .636 & .338 & .000 & .000 & .001 & .017 & .000 & .005 & .001 & .000 & .000 & & & & & & \\
\hline \multirow[t]{2}{*}{16} & Disruption of livelihood & Correlation Coefficient & $.179^{* *}$ & .028 & -.102 & -.070 & -.013 & $.281^{* *}$ & $.323^{* *}$ & $.158^{*}$ & $.193^{* *}$ & $.211^{* *}$ & $.153^{*}$ & $.317^{* *}$ & $.317^{* *}$ & $.282^{* *}$ & $.216^{* *}$ & 1.000 & & & & \\
\hline & & Sig. (2-tailed) & .005 & .668 & .113 & .274 & .836 & .000 & .000 & .014 & .002 & .001 & .017 & .000 & .000 & .000 & .001 & & & & & \\
\hline \multirow[t]{2}{*}{17} & Destruction of property & Correlation Coefficient & . $181^{* *}$ & .025 & $-.155^{*}$ & .039 & $.126^{*}$ & $.479^{* *}$ & $.468^{* *}$ & $.217^{* *}$ & $.270^{* *}$ & $.479^{* *}$ & $.395^{* *}$ & $.316^{* *}$ & $.377^{* *}$ & $.291^{* *}$ & $.574^{* *}$ & $.273^{* *}$ & 1.000 & & & \\
\hline & & Sig. (2-tailed) & .005 & .702 & .015 & .547 & .050 & .000 & .000 & .001 & .000 & .000 & .000 & .000 & .000 & .000 & . 000 & .000 & & & & \\
\hline \multirow[t]{2}{*}{18} & $\begin{array}{l}\text { Worrying about loss of house } \\
\text { value }\end{array}$ & Correlation Coefficient & $.388^{* *}$ & -.067 & -.102 & . 077 & . 047 & $.442^{* *}$ & $.380^{\circ *}$ & $.308^{* *}$ & $.272^{* * *}$ & $.401^{* *}$ & $.412^{* *}$ & $.302^{* *}$ & $.323^{* *}$ & $.310^{* *}$ & $.302^{* *}$ & $.205^{* *}$ & $.416^{* *}$ & 1.000 & & \\
\hline & & Sig. (2-tailed) & .000 & 297 & .111 & .231 & .470 & .000 & .000 & .000 & .000 & .000 & .000 & .000 & .000 & .000 & . 000 & .001 & .000 & & & \\
\hline \multirow[t]{2}{*}{19} & Increase in insurance premium & Correlation Coefficient & $249^{* *}$ & -.044 & $-.147^{*}$ & . 095 & . 099 & $.221^{* *}$ & .331" & $.223^{* *}$ & $.134^{*}$ & $.224^{* *}$ & $.333^{* *}$ & $.279^{* *}$ & $.236^{*}$ & $.237^{* *}$ & .105 & $.168^{* *}$ & $.250^{* *}$ & .399* & 1.000 & \\
\hline & & Sig. (2-tailed) & .000 & .497 & .022 & .141 & .125 & .001 & .000 & .000 & .037 & .000 & .000 & .000 & .000 & .000 & .104 & .009 & .000 & .000 & & \\
\hline \multirow[t]{2}{*}{20} & $\begin{array}{l}\text { Inability to obtain insurance } \\
\text { cover }\end{array}$ & Correlation Coefficient & $.195^{* *}$ & -.072 & $-.152^{*}$ & -.027 & -.031 & . 083 & $.253^{* *}$ & $.218^{* *}$ & $.185^{* *}$ & $.135^{*}$ & $.238^{* *}$ & $.191^{* *}$ & $.196^{* *}$ & $.227^{* *}$ & $.204^{* *}$ & $.154^{*}$ & $.177^{* * *}$ & $.244^{* *}$ & $.551^{* *}$ & 1.000 \\
\hline & & Sig. (2-tailed) & .002 & .263 & .018 & .675 & .634 & 198 & .000 & .001 & .004 & .036 & . 000 & . 003 & .002 & .000 & .001 & .016 & .006 & .000 & .000 & \\
\hline
\end{tabular}




\section{Willingness to pay (WTP) by occupation of respondents}

The mean WTP values based on occupation of respondents were analysed. Figure 4 shows that respondents in professional/managerial occupation recorded the lowest mean WTP value (£355) to avoid impact of flooding. Clerical and other white collar occupational category recorded the highest mean WTP values (£449), whilst semi-skilled and retired respondents showed mean WTP to avoid impact of flooding of $£ 407$ and $£ 387$ respectively. Respondents with skilled manual occupation recorded highest mean WTP value to avoid psychological effect of flooding. The pattern of distribution of mean WTP values to avoid psychological effect of flooding by occupation of respondents is not similar to the recorded mean WTP value to avoid impact of flooding. It can be inferred from this result that respondent's stated WTP value is not strongly related to the occupation of household income earners.

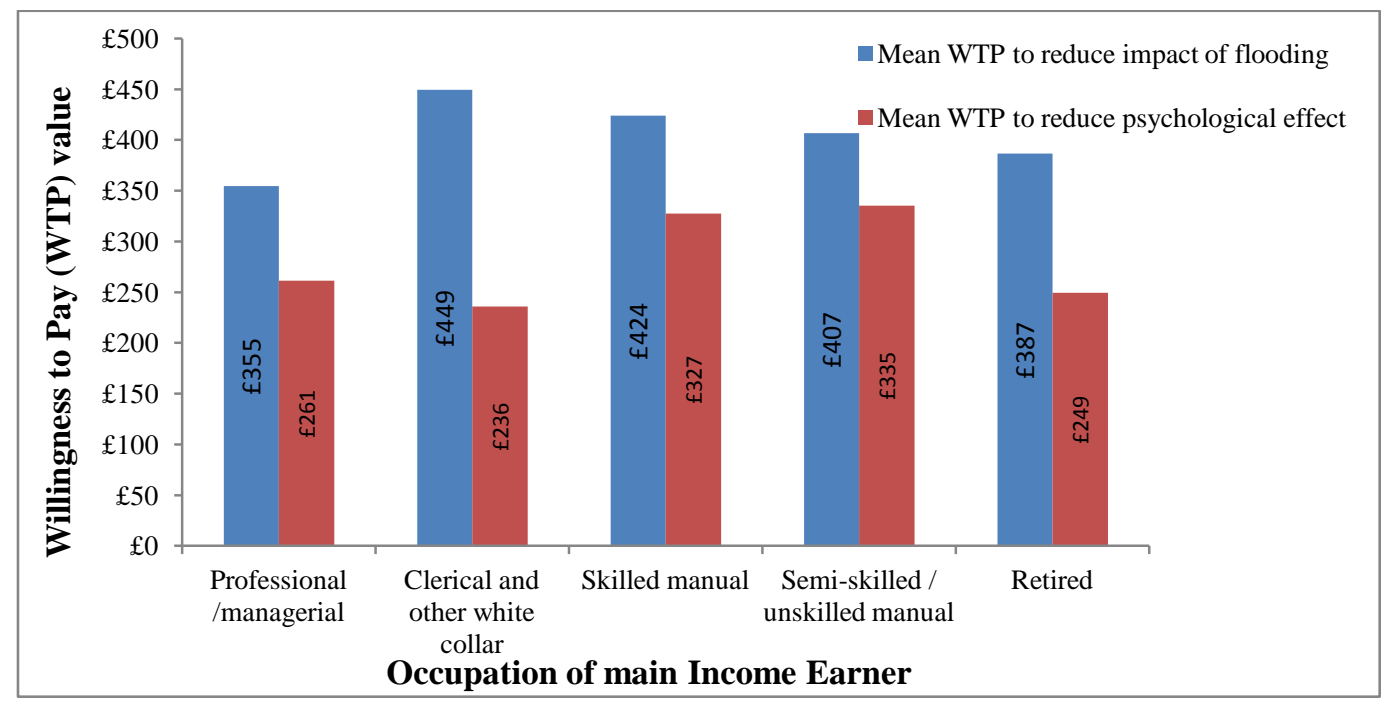

Figure 4 Mean WTP values based on respondents' occupation

\section{Willingness to pay (WTP) by age}

From the result of correlation analysis shown in Table 4, there is a weak negative correlation between the age of respondents and the value of WTP to avoid impact flooding on households with correlation coefficient $r_{s}=0.078$. By comparing the mean WTP values across age brackets, figure 5 shows that younger people are willing to pay less to avoid impact and psychological effects of flooding on households. This shows that as the respondents' age increases the WTP value also increases up to the age bracket $65-74$. The highest mean WTP values based on age brackets were recorded by respondents in age brackets 65-74 (£444 and $£ 278$ to avoid flood impact and psychological effect respectively). It can be inferred from Figure 5 that age is a determining factor of WTP values stated by respondents, further it can be inferred that there is a linear relationship between age and WTP values up to age 74 years). This could be as a result of likelihood of the ease of relocation of younger generation when compared with elderly people, hence the effect on how much younger people are willing to pay. 


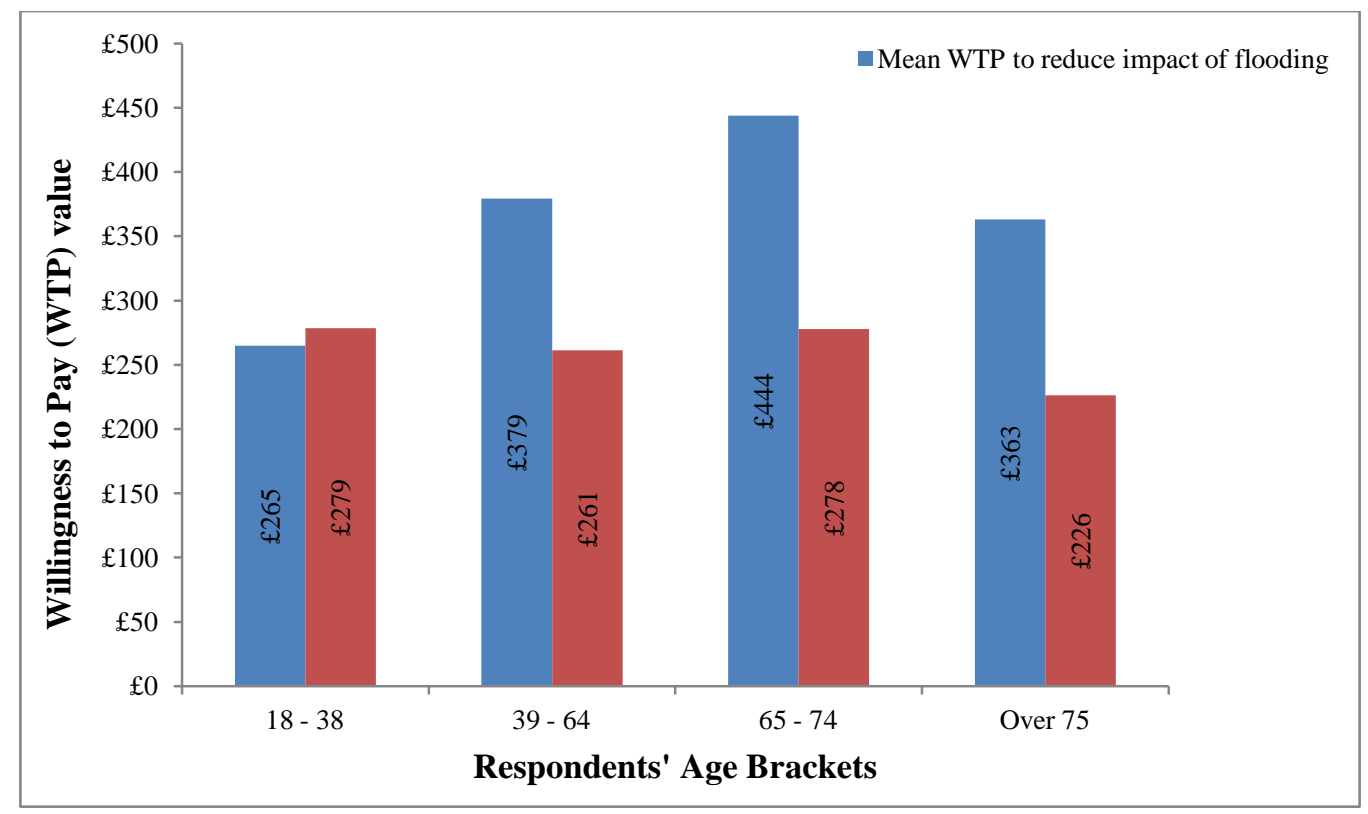

Figure 5 Mean WTP values based on respondents' age

\section{Willingness to pay (WTP) by number of people in household}

As indicated in Figure 6 the mean WTP values to avoid flood impacts for on households only incremental difference between one and more than one households property, the same pattern is mirrored when compared with households with four and over 6 people. However, the result is different when compared with the mean WTP value to avoid psychological effect of flooding on household. Mean WTP values for households with 2-3 and 4-6 persons are in the same range ( $£ 263$ and $£ 268$ respectively), surprisingly the mean WTP value for household with over 6 members was the least (£40). Further interrogation was carried out on this particular case and it was discovered that the low value result (£40) was due to low sample in this category $(n=2)$. Additionally the result shows that one-person households have the highest mean WTP to reduce psychological effect of flooding, although the effect is marginal, this can be as a result of the fact that such households may suffer more psychological effect because of non availability of household members to discuss and share the burden that comes along with flood events. 


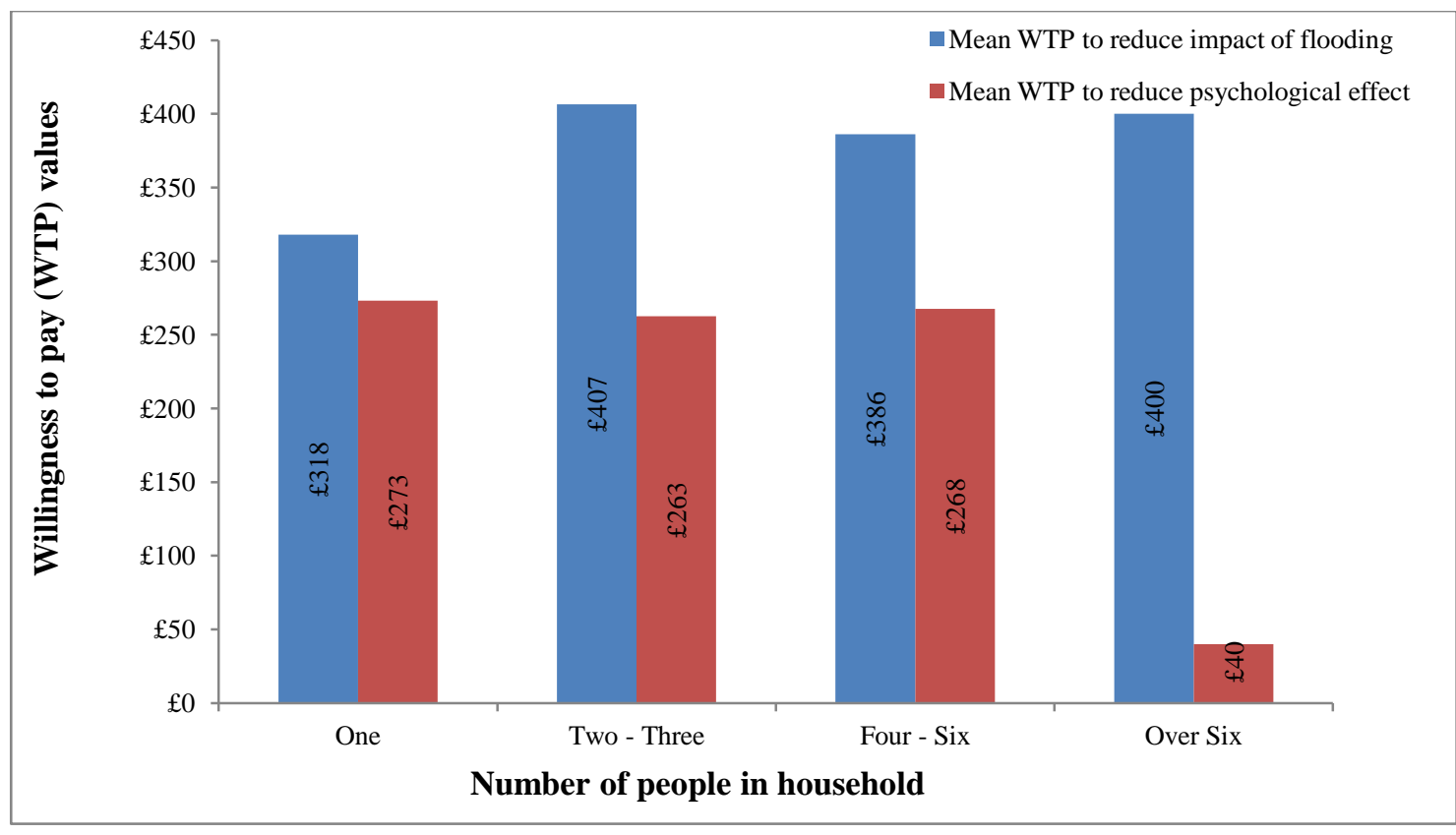

Figure 6 Mean WTP values based on number of people in each household

\subsection{Value of intangible benefits of PLFRA measures}

Following the review of the factors which has the potential to influence respondents' WTP values, detailed analyses of the data were carried out to establish the value of intangible benefit of PLFRA measures based on respondents' stated WTP values. Table 3, presents the results of the analysis. The median WTP value to avoid intangible impact of flooding on households is $£ 300 /$ household per year; while the mean WTP is $£ 390 /$ household per year. Conversely, the median WTP value to avoid psychological effect of flooding on household is $£ 200 /$ household per year and the mean WTP to avoid impact of flooding on household is $£ 263 /$ household per year. The combined median and mean WTP values to avoid impact and psychological effect of flooding on household are $£ 500$ and $£ 653$ per household per year.

Table 3 Summary Statistics for WTP to avoid impact and psychological effect of flooding on households

\begin{tabular}{lccc}
\hline \multicolumn{4}{c}{ Non-parametric statistics } \\
\hline & $\begin{array}{c}\text { Willingness to pay to } \\
\text { reduce impact of } \\
\text { flooding/year }\end{array}$ & $\begin{array}{c}\text { Willingness to pay to } \\
\text { reduce psychological } \\
\text { effects/year }\end{array}$ & $\begin{array}{c}\text { Combined WTP } \\
\text { per household per } \\
\text { year }\end{array}$ \\
\hline \multirow{2}{*}{$\mathrm{N}$} & 243 & 243 & \\
\cline { 2 - 5 } Valid & 0 & 0 & $£ 653$ \\
\hline Mean & $£ 390$ & $£ 263$ & $£ 500$ \\
\hline Medissing & 22.40 & 17.84 & \\
\hline Std. Devian of Mean & $£ 300$ & $£ 200$ & \\
\hline Maximum & $£ 349$ & 2,000 & \\
\hline \hline
\end{tabular}

In CVM research of environmental and cultural goods, mean WTP is still preferred to median WTP as an indicator of the intangible benefits, (see for example, Vaughhan et al., (1999); Environment Agency and DEFRA, (2005) and Atkinson et al., (2008)), although, these were based on a project level as against individual household level which is the focus of this 
research. Therefore the mean value of $£ 653 /$ household per year representing the value of intangible benefits of implementing PLFRA measures is hereby presented. This is greater than the $£ 200 /$ household per year that has been used since 2004 as the value of intangible benefits of flood protection measures which was established in the study carried out on behalf of Environment agency in 2004 (Environment Agency and DEFRA, 2005).

The recent study carried out by JBA (2013) on behalf of DEFRA, uses the value of $£ 1,065$ as the value of intangible benefits of investing in flood adaptation measures, the figure was based on the existing $£ 225$ per household per year (EA/DEFRA, 2005), with the addition of general practitioner (GP) care cost of $£ 970$, which accounted for medical and productivity costs for an average of four months. This shows that the existing $£ 225$ per household per year for householder intangible is still being used despite the fact that it was considered to be very low by many researchers. This revised figure of over $£ 1000$ is suitable to be used when considering economic benefit of investing in flood protection measure, however, this figure can still be interpreted as not taking fully into account the intangible impacts that are not related to extra GP visits and time off work. From the homeowner's point of view, which is the focus of this article, the value of $£ 653$ per household per year is the value of intangible benefit of investing in flood protection measures. This is based on the fact that homeowners will not take into account the cost of medical care, simply because they do not normally pay for it, similarly, they will not consider loss of productivity because they do not suffer it, these are all intangible impacts on government institutions and businesses. Conversely, if economic cost benefit analysis is to be carried out, the results presented in this article suggested a figure of $£ 970$ plus $£ 653$ ( $£ 1,623$ ) should be used, as this will take into account all the intangible impacts to institutions, businesses and households.

Another similar study carried out by Owusu, et.al (2013), the findings from this study shows that the average amount respondents were willing to invest to protect their properties against flood risk was £795. Although, this study is somewhat different from both the research reported in this article and the JBA (2013) research, however, the study uses similar method in eliciting respondent's willingness to pay. It is possible to mis-interpret the result of the study to mean that the value of $£ 795$ represents the value of intangible benefits of flood protection measure whereas, in fact, the study was not specific in the range of impacts the respondents were WTP to reduce.

\section{Conclusions}

Despite the consensus in the extant literature that the intangible impacts of flooding are important to homeowners. There has been a limited research towards quantifying these impacts. This is partly due to the difficulty in assessing these impacts in monetary terms, thus previous studies often make just passing reference to these intangibles and acknowledge that they could be important. Knowledge of the monetary value of these impacts has the potential to assist in making decisions on whether to invest in flood protection measures or not. 
A comprehensive assessment of the value of intangible benefits of investing in PLFRA measures has been carried out and the findings have been presented. The results presented have provided the much needed information on some of the key issues surrounding the assessment of the intangible benefits of property level flood risk adaptation measures. Preexisting household characteristics, such as household income and occupation were found to have weaker effects on the respondent's stated WTP values; this is in contrast to economic theory, which links WTP value to income. However, factors such as stress of flooding and worrying about future flooding were found to have strong correlation with the household's stated WTP values, and this is interpreted as a cross correlation effect of flood severity.

Thus, the value of intangible impacts of flooding on households has been assessed using the WTP values of homeowners. A distinctive insight has been gained and the intangible benefit of adopting PLFRA measures from the homeowners' perspective has been established as $£ 653$ per household per year. This finding contrast with previous research of Environment Agency and DEFRA in suggesting a higher value to reducing the intangible impacts of flooding on households, however, other recent study have estimated the value of intangible benefit of PLFRA measures of over $£ 1000$. The main difference being that this recent study is based on investigating benefits to the government as against the benefits to homeowner which is the basis of the findings presented in this article.

The main implication of the research findings is that when carrying out cost benefit analysis (CBA) of investing in flood protection measures, most especially when the CBA analysis is being carried out on an individual property basis, the value of intangible impacts presented in this article can be used to account for the benefits of the flood protection measures, thereby providing more robust decision making information, which would take into account both tangible and intangible benefits. Further, the use of the value of $£ 653$ per household per year in carrying out financial cost benefit analysis of PLFRA measures will invariably demonstrate the investment in the measures as more beneficial for properties located in low flood risk area when compared with similar analysis carried out by using the value of $£ 225$ from the Environment Agency and DEFRA research. In addition to this, if the interest of the analyst is on economic cost benefit of PLFRA measures, the value of $£ 653$ can be used, however, it is suggested that a figure of $£ 970$ should be added to the figure presented in this article to take account of cost of extra GP visits and loss of productivity, therefore suggesting total value of $£ 1,623$ per household per year.

\section{REFERENCES}

ABI (2003) Assessment of the cost and effect on Future Claims of Installing Flood Damage

Resistant Measures. Association of British Insurers: London.

ABI (2006) Flood resilient homes - what homeowners can do to reduce flood damage. Association of British Insurers: London.

ABI (2008) The Summer Floods 2007: one year on and beyond. Association of British Insurers: London.

ABI (2010) Fighting flood risk together. Association of British Insurers: London. 
Alberini, A. (2004), Robustness of VSL Estimates From Contingent Valuation Studies, Prepared for the US Environmental Protection Agency. http://yosemite.epa.gov/ee/epa/eermfile.nsf/vwAN/EE-0483-05.pdf/\$File/EE-0483$\underline{05 . p d f}$

Atkinson, G., Mourato, S., Szymanski, S., and Ozdemiroglu, E. (2008), Are We Willing to Pay Enough to Back the Bid?: Valuing the Intangible Impacts of London's Bid to Host the 2012 Summer Olympic Games," Urban Studies, 45, 2, 419-444.

Beddoes, D. W. and Booth, C. (2011) Property level flood adaptation measures: A novel approach. International Journal of Safety and Security Engineering, 1 (2). pp. 162181. ISSN 2041-9031

Bichard, E. and Kazmierczak, A. (2009) Resilient Homes: Reward-based methods to motivate householders to address dangerous climate change: A report for the Environment Agency. University of Salford, Greater Manchester.

Birol, E., Karousakis, K. and Koundouri, P. (2006) Using economic valuation techniques to inform water resources management: A survey and critical appraisal of available techniques and an application. Science of the Total Environment, 365(1-3), pp.105122.

Blaikie, N. (2010) Designing Social Research: The Logic of Anticipation. Polity Press. Cambridge:

Bowker, P., Escarameia, M. and Tagg, A. (2007) Improving the flood performance of new buildings: flood resilient construction. Guidance produced by a consortium of CIRIA, HR Wallingford Ltd, Leeds Metropolitan University, WRc and Waterman Group. RIBA Publishing. London.

https://www.gov.uk/government/uploads/system/uploads/attachment_data/file/7730/fl ood_performance.pdf

Broberg, T. (2010), Income Treatment Effects in Contingent Valuation: The Case of the Swedish Predator Policy, Environ Resource Economics, 46, 1-17.

Environment Agency, (2007) Review of 2007 Summer Floods. Bristol: Environment Agency.

Environment Agency (2009) Flooding in England: A National Assessment of Flood Risk. Environment Agency. Bristol

Environment Agency and DEFRA (2005) The Appraisal of Human Related Intangible Impacts of Flooding. Joint DEFRA/EA R\&D technical report FD2005/TR, DEFRA/EA.

Environment Agency (2010) Flood and Coastal Erosion Risk Management Appraisal Guidance (FCERM-AG): Environment Agency. Bristol.

Evans E., Ashley R., Hall J., Penning-Rowsell E., Saul A., Sayers P., Thorne C. and Watkinson A. (2004). Foresight Future Flooding. Scientific Summary: Volume I Future risks and their drivers. Office of Science and Technology. London.

Fay, M., Block, R., Carrington, T., and Ebinger, J. (2009). Adapting to Climate Change in Europe and Central Asia. World Bank, http://www.worldbank.org/eca/climate/ECA_CCA_Full_Report.pdf

Field, A. (2009) Discovering Statistics Using SPSS Third ed. Sage Publications. London

Flood Repair Forum (2006) Repairing flooded buildings: an insurance industry guide to investigation and repair. BRE Press. Watford

Gee, K. and Burkhard, B. (2010) Cultural Ecosystem Services in the context of Offshore Wind Farming: A Case Study from the West Coast of Schleswig-Holstein. Ecological Complexity, 7, pp.349-358.

Green, C. H. and Penning-Rowsell, E. C. (1989) Flooding and the Quantification of 'Intangibles'. Water and Environment Journal, 3(1), pp.27-30. 
Grothmann T. and Reusswig F. (2006) People at risk of flooding: why some residents take precautionary action while others do not. Natural Hazards, 38, (1), 101-120.

Halcrow (2009) Assessing the Benefits of Flood Warning: Phase 3, Halcrow Group Ltd. for SEPA (Scottish Environmental Protection Agency), SNIFFER, Edinburgh.

Harries, T. (2007) Householder responses to flood risk. The consequences of the search for ontological security. A thesis submitted to Middlesex University in partial fulfilment of the requirements for the degree of Doctor of Philosophy. Thesis, Middlesex University.

Hashimoto, K., Nakamura, T., Wada, I., Yoshida, K., Satoh, S., Abo, M. Seta, H., and Ohashi, M. (2006) How Great is Willingness to Pay for Recovery from Sequelae after Severe Traumatic Brain Injury in Japan? Journal of Rehabilitation Medicine, 38, pp. 141-143.

IPPC (2007) Climate change 2007: The physical science basis. Contribution of working group I to the fourth assessment report of the Intergovernmental panel on climate change. Cambridge University press, Cambridge.

IPCC (2012) Managing the risks of extreme events and disasters to advance climate change adaptation. A special report of working groups I and II of the intergovernmental panel on climate change. Cambridge University Press, Cambridge

JBA (2005) Scoping Study into the Cost of Flooding Using the August 2004 event as a case study. Scottish Executive. Edinburgh

JBA (2012) Evaluation of the DEFRA Property-level Flood Protection Scheme. Environment Agency. Bristol.

JBA, (2013) Establishing the Cost Effectiveness of Property Flood Protection: FD2657. Final Report. Department for Environment Food and Rural Affairs, London

Jha, A.K. Bloch, R. Lamond, J. (2012) Cities and flooding: A guide to integrated urban flood risk management for the $21^{\text {st }}$ century. The World Bank. Washington D.C.

Joseph, R., Proverbs, D., Lamond, J. and Wassell, P. (2011a) A critical synthesis of the intangible impacts of flooding on households. International conference in building resilience: Interdisciplinary approaches to disaster risk reduction and the development of sustainable communities. Sri Lanka.

Joseph, R., Proverbs, D., Lamond, J. and Wassell, P. (2011b) An analysis of the costs of resilient reinstatement of flood affected properties: A case study of the 2009 flood event in Cockermouth. Structural Survey, 9(4), pp.279-293.

Koerth J., Vafeidis A., Hinkel J. and Sterr H. (2013). What motivates coastal households to adapt pro-actively to sea-level rise and increasing flood risk? Regional Environmental Change, 1-13.

Kreibich H., Seifert I., Thieken, A. H., Lindquist E., Wagner K. and Merz B. (2011). Recent changes in flood preparedness of private households and businesses in Germany. Regional Environmental Change 11, 59-71

Lekuthai, A. and Vongvisessomjai, S. (2001) Intangible Flood Damage Quantification. Water Resources Management, 15(5), pp.343-362.

Lloyd's (2008) Coastal communities an climate change. Maintaining Future Insurability. London. http://www.lloyds.com/ /media/lloyds/reports/360/360\%20climate\%20reports/360_c oastalcommunitiesandclimatechange.pdf

Mark, E. K. (2008) Building human resilience: the role of public health preparedness and response as an adaptation to climate change. American Journal of Preventive Medicine, 35(5), pp.508-516.

Markandya, A. (1997) Granges Action Plan-CVM for Rivers Water Quality of the Granges River. Report for Government of India and DFID. 
Mitchell, R. C. and Carson, R. T. (1989) Using surveys to value public goods: the contingent valuation method. Johns Hopkins University Press. Baltimore

Office of the Deputy Prime Minister (2003) Preparing for Floods Interim guidance for improving the flood resistance of domestic and small business properties. ODPM Publications Centre. London

O'Garra, T., Mourato, S., Garrity, L., Schmidt, P., Beerenwinkel, A., Altmann, M., Hart, D., Graesel, C., and Whitehouse, S. (2007) Is the Public Willing to Pay for Hydrogen Buses? A Comparative Study of Preferences in Four Cities, Energy Policy, 35, 36303642.

OST (2007) Climate Change Science. Postnote No. 295. Parliamentary Office of Science and Technology, London.

Owusu, S. Wright, G. and Arthur, S. (2013) Public attitudes towards flooding and property level flood protection measures. International conference on flood resilience; experiences in Asia and Europe. 5- $7^{\text {th }}$ September 2013, Exeter, United Kingdom

Özbafli, A (2011): Estimating the willingness to pay for a reliable electricity supply in the Turkish Republic of Northern Cyprus. Doctor of Philosophy (PhD). Thesis, University of Birmingham.

Penning-Rowsell, E., Johnson, C., Tunstall, S., Tapsell, S., Morris, J., Chatterton, J. and Green, C. (2005) The benefits of flood and coastal risk management: A manual of assessment techniques. Flood Hazard Research Centre: Middlesex University Press.

Pitt, M. (2008) The Pitt review - Learning lessons from the 2007 floods. H.M. Government Cabinet Office. London

Priest, S., Tapsell, S. and Parker, D. (2008) New developments in maximizing flood warning response and benefit strategies. in Flood Risk Management: Research and Practice. CRC Press.

Proverbs, D. and Lamond, J. (2008) The barriers to resilient reinstatement of flood damaged homes. Proceedings of 4th International i-Rec Conference-Building Resilience: Achieving Effective Post-disaster Reconstruction. Christchurch, New Zealand.

Proverbs, D. and Soetanto, R. (2004) Flood Damaged Property: A guide to repair. Blackwell, Oxford.

Ramanathan, C; Narayanan, S.P. and Idrus, A.B. (2012) Construction delays causing risks on time and cost - a critical review, Australasian Journal of Construction Economics and Building, 12 (1) 37-57

Royal Haskoning (2012) Assessing the Economic Case for Property Level Measures in England. Committee on Climate Change. Peterborough.

Soetanto, R., Proverbs, D. G., Samwinga, V. and Lamond, J. E. (2008) Strategies towards attaining flood resilience. in Bosher, L. (ed.) Hazards and the Built EnvironmentAttaining Built-in resilience. London: Taylor \& Francis Group, pp.124-149.

Stuart-Menteth, A. (2007) U.K. Summer 2007 Floods. Risk Management Solutions, Inc. Newark, USA.

Tapsell, S. M., Penning-Rowsell, E. C., Tunstall, S. M. and Wilson, T. L. (2002) Vulnerability to flooding: health and social dimensions. Flood Hazard Research Centre, Middlesex University

Thurston, N., Finlinson, B., Breakspear, R., Williams, N., Shaw, J. and Chatterton, J. (2008) Developing the Evidence Base for Flood Resistance and Resilience. Joint Defra/EA Flood and Coastal Erosion Risk Management R\&D. DEFRA. London.

UKCIP (2009) UK Climate Projections. UK Climate Impacts Programme, Defra. http://www.defra.gov.uk/publications/files/pb13274-uk-climate-projections-

090617.pdf (accessed 14 December 2013). 
Vaughan, W.J., Russell, C.S., Rodriguez, D.J., and Darling, A.C. (1999), “Central Tendency Measures of Willingness to Pay from Referendum Contingent Valuation Data: Issues and Alternatives in Project Analysis," Washington, D.C.

Walker, G., Deeming, H., Watson, N., Kasheri, E., Tapsell, S., Twigger-Ross, C. and Fernandez-Bilbao, A. (2008) Flood warning in the UK. in Flood Risk Management: Research and Practice. CRC Press.

Warren, R., Tindle, A. and Whalley, R. (2011) Flood Resilient Repairs and Resistance Measures: Qualitative and Quantitative research to examine the views of consumers. ABI Research Paper No 28. Association of British Insurers. London

Wassell, P., Ayton-Robinson, R., Robinson, D., Joseph, R., Hack, K., Butler, D., Salkeld, I. and Twomey, J. (2009) Resilient Reinstatement: The costs of flood resilient reinstatement of domestic properties. Association of British Insurers. London.

Wedawatta, G., Ingirige, B. and Proverbs, D. (2013) Small- and medium-sized enterprises and flood impacts: the case of the 2009 flood event in Cockermouth. Journal of Flood Risk Management, pp.1-12.

Werritty, A., Houston, D., Ball, T., Tavendale, A. and Black, A. (2007) Exploring the social impacts of flood risk and flooding in Scotland: Scottish Executive Social Research.

Yang J.B. and Wei P.R. (2010) Causes of delay in the planning and design phases for construction projects. Journal of Architecture Engineering, 16(2), 80-83. 